\title{
EFFECT OF COMBINED APPLICATION OF ORGANIC AND. INORGANIC FERTILIZERS ON PEANUT PRODUCTION
}

\author{
ROSALIA L. BRIONES \\ National Abaca Research Center \\ Leyte State University, Visca, Baybay, Leyte, Philippines \\ and \\ PEDRO P. PASCUAL \\ Department of Agronomy and Soil Science \\ College of Agriculture, Leyte State University. \\ Visca, Baybay, Leyte, Philippines
}

\section{ABSTRACT}

Plant height, leaf area index, number of pods per plant, and seed yield were significantly influenced by the application of organic and inorganic fertilizer combination. Plants which received inorganic fertilizer alone $\left(T_{1}\right)$ grew taller $(97.38 \mathrm{~cm})$, developed larger leaf area index $(1.06)$ and more pods per plant (102.93), and produced higher seed yield (1.80 tha $\left.\mathrm{t}^{-1}\right)$ than those subjected to $T_{0}, T_{3}$, and $T_{4}$ treatments. Plots applied solely with inorganic fertilizer generated the highest net income among the different treatments used.

KEYWORDS: Peanut. Arachis hypogaea. Organic fertilizer. Inorganic fertilizer. 


\section{INTRODUCTION}

Low crop production is usually attributed to poor soil and crop management techniques employed by farmers who could not afford to buy the necessary inputs like fertilizers to augment the inherent poor soil fertility. This is due to prohibitive cost of inorganic fertilizers as well as their scarcity at times. Continuous planting of crops without fertilizer application would result to the depletion of plant nutrients in the soil hence, farm productivity would decrease. Organic materials like cow manure, guano, chicken dung, hog waste, and carabao manure among others, which are locally available, are potential sources of plant nutrients.

With continuing increase in cost and limited supply of inorganic fertilizers, most farmers are faced with the problem of maintaining the fertility level of agricultural lands. The possibility of using organic fertilizer has been gaining interest among researchers and farmers who have realized the importance of plant and animal wastes as substitute/supplement to inorganic fertilizer. This study was conducted to evaluate the effects of combined organic and inorganic fertilizers on peanut production, to determine the appropriate fertilizer combination that will give optimum seed yield of peanut, and to assess the effects of organic and inorganic fertilizer combination on some chemical properties of the soil only.

\section{METHODOLOGY}

\section{Land Preparation}

An experimental area of $781 \mathrm{~m}^{2}$ was plowed thoroughly to a depth of 15 to $20 \mathrm{~cm}$ using a tractor-drawn implement. Plowing was done two times to - pulverize and level the soil, followed by harrowing at one week interval to allow weed seeds to germinate and eventually eliminate them. Right after the last harrowing, furrows were made at a distance of $50 \mathrm{~cm}$ apart. 


\section{Soil Sampling}

Before planting, 10 soil samples were randomly collected from the entire experimental area at $0-20 \mathrm{~cm}$ depth. All the collected samples were thoroughly mixed, composited, air-dried, pulverized, and sieved passing through a 2-mm wire mesh. The samples were analyzed for soil $\mathrm{pH}$ (potentionmetric method at 1:1 soil-water ratio); \% organic matter (modified Walkley-Black method); total N (modified Kjeldahl method); and available P (modified Olsen method) contents. At the end of the experiment, three soil samples were collected at random from within the harvestable area of each treatment plot after harvest, for the final analysis of the same parameters mentioned above.

All the analyses were done at the Soils Research, Testing and Plant Analysis Laboratory (SRTPAL) of the Department of Agronomy and Soil Science, Leyte State University, Visca, Baybay; Leyte.

\section{Experimental Design and Field Layout}

The experimental area was laid out in split plot arranged in a randomized complete block design (RCBD) with three replications. Each plot had an area of $20 \mathrm{~m}^{2}(4 \mathrm{~m} \times 5 \mathrm{~m})$ with alleyways of $1.0 \mathrm{~m}$ and $5.0 \mathrm{~m}$ between replications and between treatment plots, respectively, to facilitate field operations and management. Organic and inorganic fertilizer combinations (5) were designated as follows:

$T_{0}$ - control (no fertilizer application)

$\mathrm{T}_{1}$ - inorganic fertilizer (30-30-30 kg N, $\mathrm{P}_{2} \mathrm{O}_{5}$ and $\left.\mathrm{K}_{2} \mathrm{Oha}{ }^{-1}\right)--\left(214.28 \mathrm{~kg} \mathrm{~N}, \mathrm{P}_{2} \mathrm{O}_{5}\right.$ and $\left.\mathrm{K}_{2} \mathrm{Oha}{ }^{-1}\right)$

$\mathrm{T}_{2}$ - chicken dung $(15 \mathrm{~kg} \mathrm{~N})+$ inorganic fertilizer $\left(15-30-30 \mathrm{~kg} \mathrm{~N}, \mathrm{P}_{2} \mathrm{O}_{5}\right.$ and $\mathrm{K}_{2} \mathrm{O}$ ha" $)$ - . . .

(537.63 kg ha- chicken dung $\left.+214.28 \mathrm{~kg} \mathrm{~N}, 150 \mathrm{kgP}_{2} \mathrm{O}_{5}, 150 \mathrm{~kg} \mathrm{~K}_{2} \mathrm{Oha}^{-1}\right)$

$\mathrm{T}_{3}$ - cow manure $(15 \mathrm{~kg} \mathrm{~N})+$ inorganic fertilizer $\left(15-30-30 \mathrm{~kg} \mathrm{~N}, \mathrm{P}_{2} \mathrm{O}_{5}\right.$ and $\mathrm{K}_{2} \mathrm{O}$ ha' $)$ - . - . -

$\left(882.35 \mathrm{~kg}\right.$ ha ${ }^{-1}$ cowmanure $+214.28 \mathrm{~kg} \mathrm{~N}_{1} 150 \mathrm{~kg} \mathrm{P}_{2} \mathrm{O}_{5}, 150 \mathrm{~kg} \mathrm{~K}_{2} \mathrm{Oha}^{-1}$ )

$\mathrm{T}_{4}$ - hog manure $(15 \mathrm{~kg} \mathrm{~N})+$ inorganic fertilizer $\left(15-30-30 \mathrm{~kg} \mathrm{~N}, \mathrm{P}_{2} \mathrm{O}_{5}\right.$ and $\mathrm{K}_{2} \mathrm{O}$ ha $\left.{ }^{-1}\right)$ - . . . . .

- $\left(914.63 \mathrm{~kg} \mathrm{ha}{ }^{-1}\right.$ hog manure $\left.+214.28 \mathrm{~kg} \mathrm{~N}, 150 \mathrm{~kg} \mathrm{P}_{2} \mathrm{O}_{5}, 150 \mathrm{~kg} \mathrm{~K}_{2} \mathrm{Oha}^{-1}\right)$

${ }^{*}$ Nutrient analysis of organic materials below was used as basis for computation. chicken dung: $2.79 \%$ N; cow manure: $0.17 \%$ Nand hog manure: $1.64 \%$ N(SRTPAL, LSU January 21,2004$)$. 


\section{Fertilizer Application}

Two weeks before planting, dried chicken dung, hog manure, and cow manure were uniformly applied in the specified treatments plots and were thoroughly incorporated into the soil using carabao-drawn implement to allow their partial decomposition.

For the inorganic fertilizers, complete fertilizer (14-14-14), solophos (0$20-0)$, and muriate of potash (0-0-60) were used. The fertilizers were drilled in the furrows at planting time and were covered with thin layer of soil to prevent the seeds from getting in contact with the fertilizers.

\section{Planting}

Peanut seeds (UPL-Pn6) were planted at a distance of $50 \mathrm{~cm}$ between rows and $10 \mathrm{~cm}$ between hills with 2 seeds per hill. At two weeks after seedling emergence, they were thinned to one plant per hill to have a population of 200,000 plants per hectare.

\section{Harvesting}

Harvesting was done at 99 days after sowing when $90 \%$ of the plants have reached maturity as indicated by the wilting of stems, drying up of leaves, and pods had developed distinct ridges. The harvested pods were sundried for two days to attain a moisture content of about $14 \%$. Only the plants in the six inner rows, excluding two hills at both ends of each row, were considered for data gathering.

\section{Data Gathered}

\section{A. Agronomic Characteristics}

1. Number of days from seeding to flowering. This was determined by recording the number of days from seeding up to the time when about $85 \%$ of the plants in each treatment plot had produced flowers. 
2. Number of days from seeding to maturity. This was recorded from the date of sowing up to the time when $80 \%$ of the plants in each treatment plot had matured as shown by general yellowing of leaves and development of firm pods.

3. Average number of nodules per plant at.flowering stage. This was determined by counting the nodules of 3 samples plants selected at random taken from the border rows of each treatment plot at 46 days after planting.

4. Plant height $(\mathrm{cm})$._This was recorded by measuring at random 5selected samples plants from each treatment plot at harvest. Measurement was done from the base up to the tip of the longest main stem.

5. Leaf Area Index (LAI). Measurement of this parameter was done two months after emergence, that is, when the crop had reached its maximum vegetative growth. The length and width were taken at the broadest part of all functional leaves (green leaves) of the randomly selected 5 sample plants within the harvestable area of each treatment plot.

Leaf area index was computed by multiplying the area (length $x$ width) with a correction factor (CF) of 0.521 . The total leaf area was divided by the ground area allotted per plant. This parameter was determined by the formula below:

$$
L A I=\frac{\Sigma \text { (length } \times \text { width }) \times C F \text { of } 0.521}{\text { ground area allotted per plant }\left(500 \mathrm{~cm}^{2}\right)}
$$

6. Herbage Yield $\left(t h a^{-1}\right)$. This was obtained by weighing the herbage of peanut within the harvestable area in each treatment plot after removing the pods. Herbage weight per plot was converted into per hectare basis using the formula below: 
Herbage yield $\left(\mathrm{t} \mathrm{ha}^{-1}\right)=\frac{\text { Plot yield }(\mathrm{kg}) \times 10,000 \mathrm{~m}^{2} \mathrm{ha}^{-1}}{1,000 \mathrm{~kg} \mathrm{t}^{-1} \times \text { harvestable area }\left(10.8 \mathrm{~m}^{2}\right)}$

\section{B. Yield and Yield Components.}

1. Number of pods per plant. Developed pods of the 5 sample plants from the six inner rows within the harvestable area of each plot were counted and recorded at harvest.

2. Weight $(\mathrm{g})$ of 1,000 seeds. This was obtained by weighing 1,000 seeds randomly selected from each treatment plot.

3. Number of seeds per pod. This was determined by counting the number of seeds that developed from each of the 10 sample pods in each treatment plot and the average was taken.

4. Seed yield $\left(t h^{-1}\right)$. This was determined from the sample plants in the inner rows of each treatment plot. The pods were sundried for 2 days and then shelled. The shelled seeds were then weighed and converted to per hectare basis using the formula:

$$
\text { Seed yield }\left(\mathrm{t} \mathrm{ha}^{-1}\right)=\frac{\text { Plot yield }(\mathrm{kg}) \times 10,000 \mathrm{~m}^{2} \mathrm{ha}^{-1}}{1,000 \mathrm{~kg} \mathrm{t}^{-1} \times \text { harvestable area }\left(10.8 \mathrm{~m}^{2}\right)}
$$

\section{Harvest Index (HI)}

This is the ratio of the dry weight of seeds (economic yield) at harvest to the combined dry weights of the seeds and dry herbage yield (biological yield). This was accomplished by drying the seeds to approximately $14 \%$ moisture content while the herbage was sundried for approximately 2 weeks or until its weight became constant. High harvest index means that more photosynthates produced by the plants are translocated into the reproductive parts for the production of seed. Low 
harvest index means there is more vegetative growth in proportion to the grains formed. This parameter was computed using the formula:

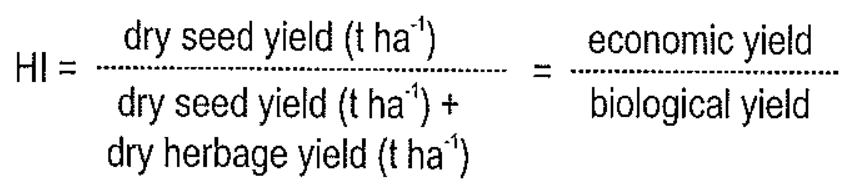

\section{Production Cost and Return Analysis Per Hectare}

Production cost was determined by recording all expenses incurred throughout the conduct of the study, from land preparation up to harvesting. Gross return was determined by multiplying the yield of each treatment plot by the current price of peanut. All expenses were computed and summed up in the determination of the most promising and economical treatment that will give the highest net return.

The total expenses from every treatment plot were subtracted from the gross income in determining the net profit with the use of the formula below:

$$
\text { Net profit }=\text { Gross Income Total Cost of Production }
$$

\section{RESULTS AND DISCUSSION}

\section{General Observations}

Mean weekly rainfall ranged from 0.0 to $33.0 \mathrm{~mm}$, minimum and maximum air temperatures from $23.3^{\circ} \mathrm{C}$ to $27.8^{\circ} \mathrm{C}$ and $32.0^{\circ} \mathrm{C}$ to $33.9^{\circ} \mathrm{C}$, respectively, and relative humidity from $68 \%$ to $83 \%$. Generally, these climatic conditions were beneficial for the vegetative growth and reproductive development of peanut throughout the conduct of the study (Knott and Deanon, 1967). However, presence of adequate moisture right 
after planting favored the emergence and rapid growth of weeds. They were controlled by handweeding using a bolo.

The general appearance of peanuts during its early growth was fairly uniform. As the crop grew, lack of moisture was noted which caused wilting of some plants. The experimental area was irrigated to minimize further injury of the crop.

Leaf spot (caused by Cercospera canescens) and root rot (caused by Sclerotium rolfsii) diseases were noted four weeks after the seedlings had emerged. However, these were controlled or minimized by spraying the plants with Benlate (Benomyl) from fourth week after planting until flowering stage at the rate of $1 / 2$ tbsp gallon of water at two-week intervals.

\section{Manure Analysis}

The organic materials used in the study were analyzed for nutrient contents beforehand. The differences on total nitrogen and phosphorous content of chicken dung, cow manure and hog manure (Table 1) could be attributed to the kind and nutrient contents of the feeds eaten by chicken, cow, and hog. Chicken and hog feeds have more protein than cow feeds, which are mainly grasses.

Table 1. Manure analysis of $\mathrm{N}$ and $\mathrm{P}$ contents under air dry basis

\begin{tabular}{lcl}
\hline \hline $\begin{array}{l}\text { Organic } \\
\text { Materials }\end{array}$ & Total N (\%) & Total P (\%) \\
\hline Chicken dung & 2.79 & 2.39 \\
Cow manure & 0.17 & 0.22 \\
Hog manure & 1.64 & 0.53 \\
\hline \hline
\end{tabular}

"Analyses were conducted at the Soll Testing and Plant Analysis Laboratory, Department of Agronomy and Soil Science, Leyte State University (LSU). 


\section{Soil Analysis}

The soil had a pH of 6.20 , contained $1.39 \%$ organic matter, with $0.07 \%$ total nitrogen, and $26.90 \mathrm{mg} / \mathrm{kg}$ extractable phosphorus (Table 2). These results indicated that the soil was slightly acidic with relatively low organic matter but with adequate amount of extractable phosphorus (PCARR, 1980).

Final soil analysis revealed that $\mathrm{pH}, \%$ organic matter, $\%$ nitrogen, and extractable phosphorus $(\mathrm{mg} / \mathrm{kg}$ ) contents of the soil were not significantly affected by the application of combined organic and inorganic fertilizers.

\section{Agronomic Characteristics}

Only plant height and leaf area index were significantly influenced by the application of organic and inorganic fertilizer combination (Table 3). Plants applied with inorganic fertilizer $\left(\mathrm{T}_{1}\right)$ alone at the rate of $30-30-30 \mathrm{~kg} \mathrm{~N}, \mathrm{P}_{2} \mathrm{O}_{5}$, $\mathrm{K}_{2} \mathrm{O} \mathrm{ha}^{-1} \mathrm{grew}$ taller $(97.38 \mathrm{~cm})$ and had the larger leaf area index (1.06) than those subjected to treatments $T_{0}$ and $T_{3}$. However, these treatment effects were comparable with those applied with $15 \mathrm{~kg} \mathrm{~N}$ from chicken dung plus 1530-30 kg N, $\mathrm{P}_{2} \mathrm{O}_{5}, \mathrm{~K}_{2} \mathrm{O}$ ha' ${ }^{-1}\left(\mathrm{~T}_{2}\right), 15 \mathrm{~kg} \mathrm{~N}$ from hog manure plus $15-30-30 \mathrm{~kg} \mathrm{~N}$, $\mathrm{P}_{2} \mathrm{O}_{5}, \mathrm{~K}_{2} \mathrm{O} \mathrm{ha}{ }^{-1}\left(\mathrm{~T}_{4}\right)$ and $15 \mathrm{~kg} \mathrm{~N}$ from cow manure plus $15-30-30 \mathrm{~kg} \mathrm{~N}, \mathrm{P}_{2} \mathrm{O}_{5}$; $\mathrm{K}_{2} \mathrm{O} \mathrm{ha}^{-1}\left(\mathrm{~T}_{3}\right)$. The application of inorganic fertilizer at the rate of $15-30-30 \mathrm{~kg}$ $\mathrm{N}, \mathrm{P}_{2} \mathrm{O}_{5}, \mathrm{~K}_{2} \mathrm{O} \mathrm{ha}^{-1}\left(\mathrm{~T}_{1}\right)$ alone provided immediate and optimum supply of available nutrients, which probably led to rapid utilization by the growing crop thus, resulted in taller plants with higher leaf area indices. Tabirao (2001) stated that plants applied with high rate of inorganic fertilizer $(30$ and $60 \mathrm{~kg} \mathrm{~N}$ ha $\left.{ }^{-1}\right)$ generally grew luxuriantly and developed bigger leaves that consequently, resulted in high leaf area index. The results indicate a direct relationship between the effect. of higher levels of nitrogen and leaf development. 
Plants in treatment plots with no fertilizer applied (To) grew shorter with lower leaf area index compared to those plants that received fertilizer $\left(T_{1}, T_{2}\right.$, $\mathrm{T}_{3}$, and $\mathrm{T}_{4}$ ).

The significant differences in LAl values and plant height as influenced by the application of combined organic and inorganic fertilizers that had no significant effect to herbage yield might be due to the number of plants per plot.

Table 2. Initial and final analyses of soil $\mathrm{pH}$, organic matter $(\%)$, total nitrogen $(\%)$, and extractable phosphorus $(\mathrm{mg} / \mathrm{kg}$ ) contents as influenced by application of combined organic and inorganic fertilizers on peanut production.

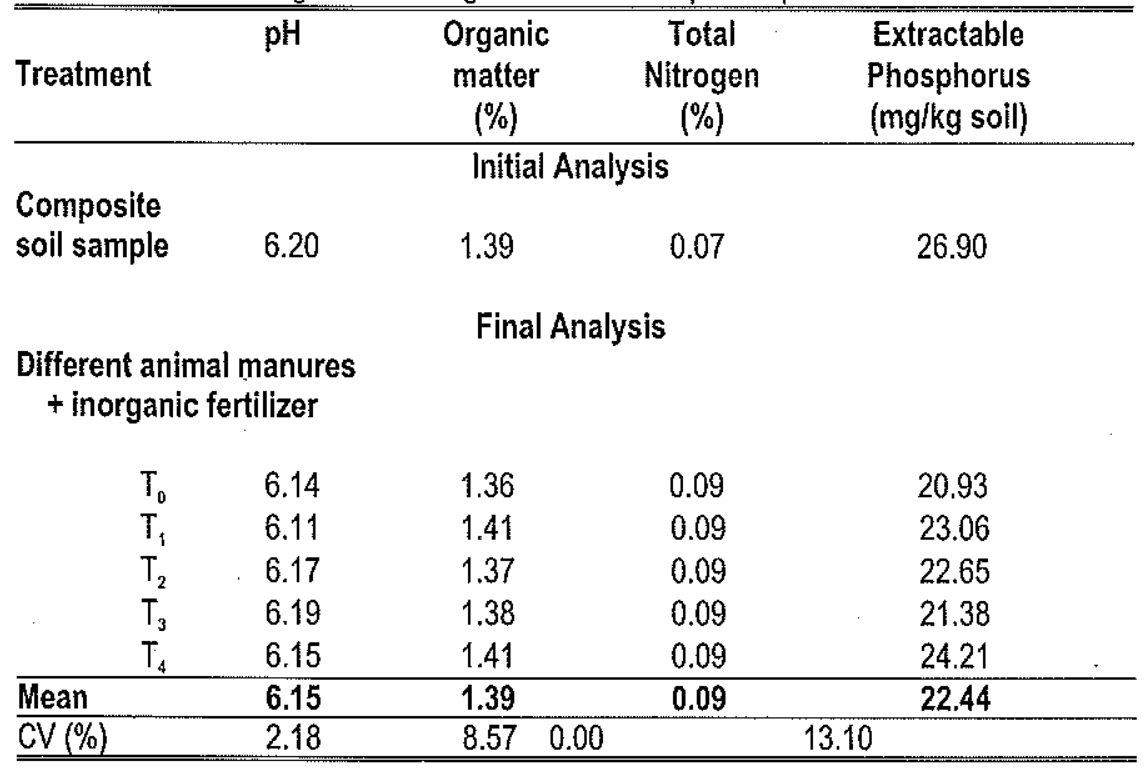

Legend:

$\mathrm{T}_{0}$ control (no fertilizer application)

$\mathrm{T}_{1}$ - inorganic fertilizer (30-30-30 $\mathrm{kg} \mathrm{N}, \mathrm{P}_{2} \mathrm{O}_{5}, \mathrm{~K}_{2} \mathrm{O}$ ha $\left.{ }^{-4}\right)$

$\mathrm{T}_{2}-15 \mathrm{~kg} \mathrm{~N}$ chicken dung $+15-30-30 \mathrm{~kg} \mathrm{~N}, \mathrm{P}_{2} \mathrm{O}_{5}, \mathrm{~K}_{2} \mathrm{O} \mathrm{ha}{ }^{-1}$

$\mathrm{T}_{3} 15 \mathrm{~kg} \mathrm{~N}$ cow manure $+15-30-30 \mathrm{~kg} \mathrm{~N}, \mathrm{P}_{2} \mathrm{O}_{5}, \mathrm{~K}_{2} \mathrm{O} \mathrm{ha}^{-1}$

$\mathrm{T}_{4} 15 \mathrm{~kg} \mathrm{~N}$ hog manure +15-30-30 kg N, $\mathrm{P}_{2} \mathrm{O}_{5}, \mathrm{~K}_{2} \mathrm{O} \mathrm{ha}{ }^{-1}$ 
Table 3. Agronomic characteristics of peanut as influenced by the application of combined organic and inorganic fertilizers.

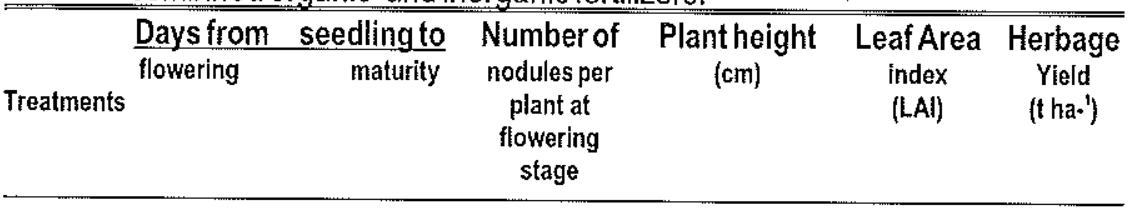

Different animal manures

+ inorganic fertilizer

$\begin{array}{lllllll}\mathrm{T}_{0} & 30.50 & 109.50 & 106.55 & 82.33 \mathrm{c} & 0.56 \mathrm{c} & 20.97 \\ \mathrm{~T}_{1} & 29.50 & 109.17 & 128.16 & 97.38 \mathrm{a} & 1.06 \mathrm{a} & 20.79 \\ \mathrm{~T}_{2} & 29.66 & 109.33 & 113.94 & 92.43 \mathrm{ab} & 0.89 \mathrm{ab} & 20.61 \\ \mathrm{~T}_{3} & 29.66 & 109.17 & 101.09 & 89.49 \mathrm{~b} & 0.67 \mathrm{~b} & 22.32 \\ \mathrm{~T}_{4} & 30.50 & 109.00 & 112.72 & 92.78 \mathrm{ab} & 0.81 \mathrm{ab} & 20.21\end{array}$

\begin{tabular}{lllllll}
\hline Mean & 29.96 & 109.23 & 112.49 & 90.89 & 0.80 & 20.55 \\
\hline CV $(\%)$ & 3.38 & 0.45 & 29.70 & 3.59 & 22.75 & 16.26 \\
\hline
\end{tabular}

Treatment means within a given factor in a column having the same letter are not significantly different from each other at $5 \%$ level of significance based on Duncan's Multiple Range Test (DMRT).

Legend:

$T_{0}$ control (no fertilizer application)

$\mathrm{T}_{1}$-inorganic fertilizer (30-30-30 $\left.\mathrm{kg} \mathrm{N}, \mathrm{P}_{2} \mathrm{O}_{5}, \mathrm{~K}_{2} \mathrm{Oha}^{-1}\right)$

$\mathrm{T}_{2}$ - $15 \mathrm{~kg} \mathrm{~N}$ chicken dung + 15-30-30 kg N, $\mathrm{P}_{2} \mathrm{O}_{5}, \mathrm{~K}_{2} \mathrm{Oha}^{-1}$

$\mathrm{T}_{3}$ 15kg.N cow manure + 15-30-30 kg N, $\mathrm{P}_{2} \mathrm{O}_{5}, \mathrm{~K}_{2} \mathrm{Oha}^{-1}$

$\mathrm{T}_{4} 15 \mathrm{~kg} \mathrm{Nhog}$ manure $+15-30-30 \mathrm{kgN}_{1} \mathrm{P}_{2} \mathrm{O}_{5}, \mathrm{~K}_{2} \mathrm{Oha}^{-1}$

\section{Yield, Yield Components, and Harvest Index of Peanut}

The application of organic and inorganic fertilizer combination on the yield and yield components as well as the harvest index of peanut were not markedly affected by fertilizer application except for the number of pods per plant and seed yield of peanut(Table 4). 
Plants that received inorganic fertilizer $\left(T_{1}\right)$ alone at the rate of 30-30-30 $\mathrm{Kg} \mathrm{N}, \mathrm{P}_{2} \mathrm{O}_{5}, \mathrm{~K}_{2} \mathrm{O}$ ha ${ }^{-1}$ developed significantly more pods per plant (102.93) and produced higher seed yield $\left(1.80\right.$ tha $\left.^{-1}\right)$ than those under $T_{0}, T_{3}$, and $T_{4}$ treatments but comparable to the effect of $15 \mathrm{~kg} \mathrm{~N}$ chicken dung plus $15-30$ $30 \mathrm{~kg} \mathrm{~N}, \mathrm{P}_{2} \mathrm{O}_{5}, \mathrm{~K}_{2} \mathrm{O} \mathrm{ha}^{-1}\left(\mathrm{~T}_{2}\right)$. This plant response suggests that inorganic fertilizers could have provided immediate supply of available nutrients to the plants allowing them to have higher seed production. Under treatment $T_{2}$, its effect could be due to rapid decomposition of the material thus, the faster nutrient release for crop use during the growing season, aside from the nutrients provided by the inorganic fertilizer.

Table 4. Yield, yield components and harvest index of peanut as influenced by the application of combined organic and inorganic fertilizers

\begin{tabular}{cccccc}
\hline \hline & Number of & Weight of & Number of & Seed & Harvest \\
Treatments & pods per & 1000 seeds & seeds per & Yield & Index \\
& plant & (g) & pod & (t ha $\left.a^{-1}\right)$ & (HI)
\end{tabular}

Different animal manures + inorganic fertilizer

$\begin{array}{lcccll}\mathrm{T}_{0} & 58.63 \mathrm{c} & 425.00 & 1.98 & 0.99 \mathrm{c} & 0.69 \\ \mathrm{~T}_{1} & 102.93 \mathrm{a} & 433.33 & 2.20 & 1.80 \mathrm{a} & 0.68 \\ \mathrm{~T}_{2} & 89.53 \mathrm{ab} & 437.50 & 2.07 & 1.51 \mathrm{ab} & 0.62 \\ \mathrm{~T}_{3} & 75.60 \mathrm{bc} & 450.00 & 2.00 & 1.14 \mathrm{bc} & 0.64 \\ \mathrm{~T}_{4} & 71.13 \mathrm{bc} & 433.33 & 1.95 & 1.41 \mathrm{~b} & 0.66\end{array}$

\begin{tabular}{lrrrrr}
\hline Mean & 79.57 & 435.83 & 2.04 & 1.37 & 0.66 \\
\hline $\mathrm{CV}(\%)$ & 13.52 & 7.35 & 12.17 & 14.45 & 8.25 \\
\hline \hline
\end{tabular}

Treatment means within a given factor in a column having the same letter are not significantly different from each other at $5 \%$ level of significance based on Duncan's Multiple Range Test (DMRT).

Legend:

To control (no fertilizer application)

$\mathrm{T}_{1}$ - inorganic fertilizer ( $\left.30-30-30 \mathrm{~kg} \mathrm{~N}_{1} \mathrm{P}_{2} \mathrm{O}_{5}, \mathrm{~K}_{2} \mathrm{Oha}^{-1}\right)$

$\mathrm{T}_{2}-15 \mathrm{~kg} \mathrm{~N}$ chicken dung $+15-30-30 \mathrm{~kg} \mathrm{~N}, \mathrm{P}_{2} \mathrm{O}_{5}, \mathrm{~K}_{2} \mathrm{Oha}^{-1}$

$\mathrm{T}_{3} 15 \mathrm{~kg} \mathrm{~N}$ cowmanure $+15-30-30 \mathrm{kgN}, \mathrm{P}_{2} \mathrm{O}_{5}, \mathrm{~K}_{2} \mathrm{Oha}^{-1}$

$\mathrm{T}_{4} 15 \mathrm{kgNhog}$ manure $+15-30-30 \mathrm{kgN}, \mathrm{P}_{2} \mathrm{O}_{5}, \mathrm{~K}_{2} \mathrm{Oha}^{-1}$ 
On the effects of different organic manures combined with inorganic fertilizer, plants applied with $15 \mathrm{~kg} \mathrm{~N}$ chicken dung with $15-30-30 \mathrm{~kg} \mathrm{~N}, \mathrm{P}_{2} \mathrm{O}_{5}$, $\mathrm{K}_{2} \mathrm{O} \mathrm{ha}^{-1}\left(\mathrm{~T}_{2}\right)$ had more pods that developed per plant at 89.53 and higher seed yield of 1.51 tha ${ }^{-1}$ compared to unfertilized plot (To), but not significantly different from those subjected to treatments $T_{3}$ and $T_{4}$.

The plant response in the unfertilized plot $\left(T_{0}\right)$ was comparable to plots applied with cow manure $\left(T_{3}\right)$ and hog manure $\left(T_{4}\right)$. The plants in the unfertilized plots might have availed nutrients from residues left by the previous crop. The performance of plants in $T_{3}$ and $T_{4}$ treatment plots could be due to the organic materials that took time to decompose hence, their nutrients could probably have not become readily available for plant use. Application of organic materials as fertilizers in the soil may enhance soil fertility and productivity, which may lead to high crop production: The long term effects could be improvement of soil fertility, soil structure, water holding capacity and tilth by promoting soil granulation

\section{Cost and Return Analysis}

On the use of the different organic materials, in combination with inorganic fertilizer in peanut plants applied with $15 \mathrm{~kg} \mathrm{~N}$ chicken dung plus 15-30-30 Kg N, $\mathrm{P}_{2} \mathrm{O}_{5}, \mathrm{~K}_{2} \mathrm{O}$ ha $\mathrm{a}^{-1}$ inorganic fertilizer $\left(\mathrm{T}_{2}\right)$ produced the highest net income of $\mathrm{P} 37,596.00$ per hectare, followed by those applied with $15 \mathrm{~kg}$ $\mathrm{N}$ hog manure plus $15-30-30 \mathrm{Kg} \mathrm{N}, \mathrm{P}_{2} \mathrm{O}_{5}, \mathrm{~K}_{2} \mathrm{O}$ ha ${ }^{-1}$ inorganic fertilizer $\left(T_{4}\right)$ with a net income of $P 34,081.00$ per hectare (Table 5). The application of $15 \mathrm{~kg} \mathrm{~N}$ cow manure plus $15-30-30 \mathrm{Kg} \mathrm{N}, \mathrm{P}_{2} \mathrm{O}_{5}, \mathrm{~K}_{2} \mathrm{O}$ ha ${ }^{-1}$ inorganic fertilizer $\left(\mathrm{T}_{3}\right)$ generated the lowest net income of $P 24,551.00$ per hectare among fertilizer-treated plants. This was comparable to that of the unfertilized plots (To) with a net income of P24,485.00 per hectare. Their differences in net income were attributed more on their effects on seed yield and less on the cost of production except under $T_{0}$ and $T_{1}$ treatments where lesser amounts of fertilizer materials and labor were used. 
Table 5. Cost and return analysis of peanut production per hectare as influenced by the application of combined organic and inorganic fertilizers

\begin{tabular}{lcccc}
\hline \hline Treatments & $\begin{array}{c}\text { Seed Yield } \\
\left(\mathrm{t} \mathrm{ha} \mathrm{a}^{-1}\right)\end{array}$ & $\begin{array}{c}\text { Gross Income } \\
\text { (I) }\end{array}$ & $\begin{array}{c}\text { Cost of } \\
\text { Production }(\mathrm{P})\end{array}$ & $\begin{array}{c}\text { Net Income } \\
(\mathrm{P})\end{array}$ \\
\hline
\end{tabular}

Different animal manures + inorganic fertilizer

\begin{tabular}{lllll}
$\mathrm{T}_{0}$ & $0.99 \mathrm{c}$ & $34,650.00$ & $10,165.00$ & $24,485.00$ \\
$\mathrm{~T}_{1}$ & $1.80 \mathrm{a}$ & $63,000.00$ & $13,589.00$ & $49,411.00$ \\
$\mathrm{~T}_{2}$ & $1.51 \mathrm{ab}$ & $52,850.00$ & $15,254.00$ & $37,596.00$ \\
$\mathrm{~T}_{3}$ & $1.14 \mathrm{bc}$ & $39,900.00$ & $15,349.00$ & $24,551.00$ \\
$\mathrm{~T}_{4}$ & $1.41 \mathrm{~b}$ & $49,350.00$ & $15,269.00$ & $34,081.00$ \\
\hline Mean & 1.37 & $47,950.00$ & $13,925.20$ & $34,024.80$ \\
\hline \hline
\end{tabular}

"Gross income was obtained by multiplying the yield with the current price of peanut in the market $(P 35.00 / \mathrm{kg})$

\section{CONCLUSION AND RECOMMENDATION}

\section{Conclusion}

Application of organic and inorganic fertilizers significantly increases plant height, leaf area index, number of pods per plant, and seed yield.

1. Application of $15 \mathrm{~kg} \mathrm{~N}$ chicken dung plus inorganic fertilizer (15-30$30 \mathrm{~kg} \mathrm{~N}, \mathrm{P}_{2} \mathrm{O}_{5}, \mathrm{~K}_{2} \mathrm{O}$ ha ${ }^{-1}$ ) seems to be the appropriate fertilizer combination that would give optimum seed yield of peanut hence, higher profit compared to the effects of other treatments of combined organic and inorganic fertilizers. 
2. Some of the chemical properties of the soil such as $\mathrm{pH}, \%$ organic matter, \% total nitrogen, and extractable phosphorus (mg/kg) contents of the soil are not significantly affected by application of organic and inorganic fertilizer combination under the conditions of this study.

\section{Recommendation}

1. It is recommended that for peanut production, $15 \mathrm{~kg} \mathrm{~N}$ chicken dung combined with inorganic fertilizer (15-30-30 kg N, $\mathrm{P}_{2} \mathrm{O}_{5}, \mathrm{~K}_{2} \mathrm{O}$ ha $\left.\mathrm{C}^{-1}\right)$ be applied to produce optimum seed yield and profit among the combined organic and inorganic fertilizer treatments.

2. Some physical properties of the soil like bulk density and soil texture of the area should be assessed.

3. A similar study be conducted in farmer's field with varying environmental conditions and soil types to determine further the effects of animal manures on the production of peanut.

4. It is also suggested that a follow-up study be conducted to determine the residual effects of different animal manures on the growth and yield of peanut.

\section{LITERATURE CITED}

CATINGAN, F. D. 1990. The Effect of Inoculation and Fertilizer Application on the Growth and Yield of Mungbean Grown Under Coconut.BSA Thesis, ViSCA, Baybay, Leyte. $66 \mathrm{pp}$.

KNOTT, J. E. and J. R. DEANON, Jr. 1967. Vegetable Production in Southeast Asia. Los Baños, Laguna, College of Agric. Univ. of the Philippines. $366 \mathrm{pp}$. 
PCARR. 1978. The Philippines Recommends for Peanut. Phil. Coun. For Agric. Res. Research. Los Baños, Laguna. 70 pp.

PCARR. 1980. Standard Method of Analysis for Soil, Plant Tissue, Water and Fertilizer. Phil. Coun. for Agric. Res. Research. Los Baños, Laguna. $164 \mathrm{pp}$.

TABIRAO, R. M. 2001. Effect of Mulching and Nitrogen Application on the Growth and Yield of Peanut. BSA Thesis. ViSCA, Baybay, Leyte. $47 \mathrm{pp}$.

WOODROOF, J. G. 1973. Peanuts: Production, Processing, Products. Westport Connecticut. AVIPub. $256 \mathrm{pp}$.

\section{ABOUT THE AUTHOR}

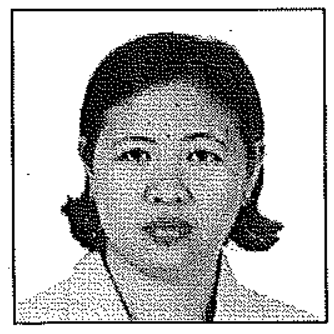

The author finished her Bachelor of Science in Agriculture major in Agronomy in April 1991 from the then Visayas State College of Agriculture (ViSCA), now the Leyte State University (LSU). She worked as Process Documentor at the Center for Social Research (CSR), now the Institute of Strategic Research and Development Studies (ISRDS) in January

1992. In March 1993, she was hired as Science Research Assistant at the LSU-based Regional Coconut Research Center (RCRC). She finished her Master of Science in Agronomy in March 2006. She is now connected with the National Abaca Research Center (NARC) as Science Research Assistant at the Tissue Culture Laboratory.

The co-author is a retired professor of the Department of Agronomy and Soil Science. 